\title{
Abuse of Dominant Market Position by Predatory Pricing; The Valio Case
}

\author{
Aarne Puisto \\ Faculty of Law, Lund University \\ Box 207, 22100 Lund, Sweden \\ Tel./Fax:+46-46-222-10-00 E-mail:aarne.puisto@gmail.com
}

\author{
Hamed Alavi \\ Tallinn Law School, Tallinn University of Technology \\ Akadeemia Tee 3, Tallinn, Estonia \\ Tel./Fax:+372-620-2430E-mail: hamed.alavi@ttu.ee
}

Submitted: Apr 7, 2016; Reviewed: Apr 19, 2016; Accepted: Apr 28, 2016

\begin{abstract}
This article analyses the competition law related to abuse of a dominant market position using strategy of predatory pricing by undertakings in the European Union and, compares the same situation to the United States 'predatory pricing law. The purpose of this article is to survey predatory pricing as a phenomenon both within and outside the EU. Article is largely centered on the case of Valio, which is still awaiting final judgment from the Supreme Administrative Court of Finland. This case was chosen as it is extremely topical and has several unique features. The findings proved that undertakings who achieved their dominant position before the recession have significant advantage over smaller undertakings. However, they cannot necessarily afford to act on the same basis for long, which is why a model closer to that of the United States would be of benefit to control some behaviors of these undertakings. Bearing in mind that the Valio case is examined under EU law, it will be interesting to see if its judgement will be remembered as the 'milk fallacy' or if it will change the face of the case law as it currently stands.
\end{abstract}

Keywords: Abuse of Dominant Position; European Competition Law; Market; Predatory Pricing

DOI: http://dx.doi.org/10.20956/halrev.v1n1.212

\section{INTRODUCTION}

This article analyses the comparative competition law related to abuse of a dominant market position using strategy of predatory pricing by undertakings in the European Union (hereinafter 'EU'). For this purpose, a precise case study of the Valio case has been made. ${ }^{1}$ Antti Aine, Adjunct Professor of general competition law at the University of Turku as expert in field of European Competition Law, has been interviewed for this

\footnotetext{
Finnish Administrative Supreme Court 12/2014, Appeal statistics. Available from: <http://www.kho.fi/material/attachments/kho/aineistoa/tilastoja/d1DGRBo1H/ KHO.fi.pdf $>$. [Accessed: 13 January 2016].
} 
article. Also EU law on predatory pricing has been compared to the United States' predatory pricing law.

The Valio case is chosen as an example as it is extremely topical in Finland and is still awaiting the final judgment of the Supreme Administrative Court of Finland (hereinafter 'FSCA'). Valio is the largest milk processing body in Finland and has been condemned with the largest penalty in history of Finnish business society. This is the first time an undertaking has been convicted for too low prices in Finland. The case has affected almost all Finnish citizen, as Finland is among the biggest consumers of milk in the world. ${ }^{2}$

The case might be difficult to grasp, because it tries to find whether or not Valio's price for the wholesalers has been set too low. Thus, it is not a question of the actual price, which is directly reflected in daily life of consumers. In Finland, the final price for consumers precedes by four steps (in this case, with respect to Valio); (i) the price the cooperatives pay to the producer, (ii) the price Valio pays to its cooperatives, (iii) the price the wholesalers pay to Valio and, (iv) the price the retailers pay their own wholesalers.

The fact that of all these prices, except the producer price and the final consumer price, are closely guarded business secrets, makes external evaluation challenging. As it will be noticed, the Valio case has a unique nature, among other things, due to the lack of clarity on the form of the ownership of Valio,

Yle 8/2013, Finns as milk consumers. Available from: $<$ http://yle.fi/uutiset/juommeko_maitoa_koska_se_on_ kannattava_bisnes/6766804>. [Accessed: 13 January 2016]. since this affects the computational division of costs

Therefore, this article explores the following research questions; whether EU Competition law policy is already excessively restrictive, and if so, what is the effect on the business development of undertakings with only one nationally dominant market position and, whether the products, which are legally classified as belonging to different product markets, belong de facto to the same product market in case of being fully interchangeable with each other?

\section{ANALYSIS AND DISCUSSION}

Predatory Pricing in the European Union

In the European Union, it is more likely that a competition authority would find an undertaking guilty of predatory pricing with too insufficient grounds rather than finding it not guilty. ${ }^{3}$ Accordingly, if an undertaking with a dominant position has a reputation of predatory actions, this reputation in itself may constitute a barrier to enter the market. ${ }^{4}$ So far the European Court of Justice (hereinafter 'ECJ') and the Commission have been reluctant to require proof of recoupment $(P$ France Télécom SA v Commission of the European Communities (2009) C-202/07, para. 113), which is a requirement in the United States to prove the existence of predatory pricing. ${ }^{5}$

The ECJ and the Commission have a variety of ways to assess predatory pricing.

Dhall, V. (2008). Competition law today: concepts, issues, and the law in practice, Oxford University Press, Oxford, pg. 83

4 Wish, R \& Bailey, D. (2012), Competition Law, $7^{\text {th }}$ edn, Oxford University Press, Oxford, pg. 739.

Rosenblatt, H, Armengod, H \& Scordamaglia-Tousis, A. (2013). "Predatory Pricing in the European Union", European Antitrust Review, pp. 21-25. 
The starting points have been average variable costs (hereinafter 'AVC'), average avoidable costs (hereinafter 'AAC') and average total costs (hereinafter 'ATC'). ${ }^{6}$ One of the best known and the most important predatory pricing cases is the case of $A K Z O$ (AKZO Chemie BV v Commission of the European Communities (1991) C-62/86).

The ECJ in this case defined two different approaches for identifying predatory pricing. First of all, undertaking's pricing can be assumed to be an abuse of a dominant position if the price falls below AVC. Secondly, if the price exceeds AVC, but is still under ATC, the undertaking is guilty of predatory pricing if evidence of a strategy to exclude competitors from the market can be found. ${ }^{7}$ However, the Commission has, in its own Communication, slightly modernized the AKZO criteria.

Currently, AAC has been chosen as the starting point and the Commission finds in most cases that it is a clear sign of selling at loss. On the other hand, the change to the previous starting point is not substantial, as often only avoidable costs are variable ones. The Commission, however, gives an example of a situation in which the undertaking has expanded its operations in order to be able to predator. In this case, the extra costs would belong to AAC, not to AVC. ${ }^{8}$

On the whole, calculating the costs is difficult because almost all of the costs are fixed in a very short term, and almost all will be variable in the very long term. Big operators usually do business on many

\footnotetext{
6 Moisejevas, R, Novosad, A \& Bitè, V. (2012). "Costs Benchmarks as Criterion for Evaluation of Predatory Pricing”, Jurisprudence, 19(2): 585-603.

AKZO (1991), para. 71-72

European Commission 2009, para. 63-64.
}

different markets and there is not a right way to share the common costs of different business area. When an undertaking operates in a number of different markets it is easier to cope with the losses it incurs if other markets are profitable. ${ }^{9}$ Valio has several products made from the same raw material i.e. milk; fresh dairy products, cheese and fats. Therefore, it operates in a number of different markets and review in this case is only based on the basic milk market enabled Valio to operate at loss on that market.

\section{Comparison to Predatory Pricing in the United States}

Judgments on predatory pricing are fairly common in the EU, which is historically the reason behind severe approach of the ECJ to similar cases. Competition law is known as antitrust law in the United States with the Sherman Act of 1890 being considered as the cornerstone of its history. ${ }^{10}$ The second section of the Sherman Act makes it illegal to acquire or maintain monopoly power through improper means.

One of the first and most famous US antitrust cases was dealt with in 1911, where the Standard Oil was summoned to the Supreme Court of the United States (U.S. Supreme Court, 1911). As a result, Standard Oil, divided into parts, because of being, inter alia, engaged in predatory pricing. ${ }^{11}$ However, predatory pricing claims in the United States have not succeeded for more than 20 years after the case of Brooke Group

\footnotetext{
Jones, A \& Sufrin, B. (2012). EU Competition Law: Text, Cases, and Materials, $4^{\text {th }}$ edn, Oxford: Oxford University Press, p. 393.

10 Sullivan, LA. (1977). Handbook of the Law of Antitrust. Berkley: West Publishing Co., p. 1.

$11 \quad$ Ibid. p. $35-36$
} 
v. Brown \& Williamson Tobacco (U.S. Supreme Court, 1993).

In that case, the Supreme Court of the United States gave two requirements to the plaintiff, which need to be proved to indicate that the accused is guilty of predatory pricing:

(1) The prices of an undertaking which receive complain are below an appropriate measure of its rival's costs, and

(2) The competitor had a reasonable prospect of recouping its investment in below cost prices. Without recoupment, even if predatory pricing causes the target painful losses, it produces lower aggregate prices in the market, and consumer welfare is enhanced. ${ }^{12}$

In the United States the starting point, unlike in the EU, decision on whether or not predatory pricing has taken place is on the basis of the fact that the undertaking should be able to recover losses. ${ }^{13}$ Even though the economic context plays a major role in US Competition law, politics also have a significant impact, either in the legislative process or enforcement actions taken by the competition authorities of the United States. ${ }^{14}$

In the EU, according to Article 2(3) of the Treaty on European Union, the internal market of the Union is based on "a highly competitive social market economy". Antti Aine sees the comparison between the EU and the United States as challenging, because basic principles are quite different. The market in the United States is seen as

12 U.S. Supreme Court, 1993, pp. 9-34

13 Dhall, 2008, Op.Cit., p. 72

14 Dabbah, M. (2010). International and Comparative Competition Law, New York: Cambridge University Press, p. 256 much more self-directed, while a need to control the market exists in the EU.

\section{The Valio Case}

Competition law in Finland is mainly regulated by Kilpailulaki, which was harmonized with the European Union competition rules in 2011. Kilpailulaki's Article 7 is almost word-for-word translation of Article 102 of the Treaty on the Functioning of the European Union. If the EU competition rules' trade criterion is fulfilled, the national competition authority is also required for complying with it. The proposed penalty shall always exceed the benefit that was achieved by the illegal actions and it shall be based on the revenue of the economic unit to which it belongs. ${ }^{15}$ Therefore, in the Valio case the revenue of the entire Valio Group is considered, not just the revenue of its basic milk unit.

\section{Background of the Valio Case}

A Danish-Swedish concern Arla Foods acquired control of Ingman Foods Oy from Finland in 2007 and ultimately acquired a 100 per cent ownership in 2008. The undertaking operated in Finland as Arla Ingman until May 2014, when it changed the name to Arla (for reasons of clarity both are referred to as Arla Finland).

Regarding revenue, Arla Foods is more than four times bigger than Valio. ${ }^{16}$ After Valio modified its pricing policy from beginning of the year 2010, Arla Finland,

15 Alkio, M \& Wik, C. (2009). Kilpailuoikeus. Helsinki: Talentum, p. 819

16 In 2012 Valio's revenue was approximately 2 billion Euro (Valio 2013), whereas Arla Foods's revenue was close to 8.5 billion Euro (Dairy Foods 2013). Respectively, Arla Finland 's revenue is approximately 379 million Euro (Arla 2014) 
Valio's most significant competitor in the Finnish dairy market, made a new request for action to the Finnish Competition Authority (hereinafter ' $F C A$ ') ${ }^{17}$ on May 7, 2010. Two other dairies also approached the FCA on the same subject. ${ }^{18}$ Valio consulted the head of the FCA before changing their pricing policy where the head of the FCA replied that the new pricing policy was not likely to be illegal. ${ }^{19}$

\section{The Decision of the Finnish Competition Authority}

Since the content of the FCA's decision in the Valio case is very similar to the judgment of the Finnish Market Court (hereinafter 'FMC'), this sub-chapter emphasizes mainly those issues which belong to that part of the process. Valio appealed to the FMC for both provisional prohibitions of implementing the FCA's decision and to revoke it in its entirety. The FMC rejected Valio's application to provisionally prohibit the implementation of the FCA's decision on June 26, 2013, suspending Valio's discounted prices (Finnish Market Court, 2013).

The FMC justified its decision on the grounds that Valio had, by its own initiative, announced an increase of prices before lodging the appeal (Finnish Market Court 6/2013). If the FMC had accepted Valio's appeal, it would have resulted in a change of already modified prices, which in practice, would have adversely impacted consumers. The FCA informed Valio later about decision, and its penalty proposal, to

\footnotetext{
17 At the beginning of the year 2013, the FCA was combined with the Finnish Consumer Authority, but the for reasons of clarity only 'FCA' will be used.

18 Finnish Competition Authority, 2012, para. 11

19 Yle, 2014.
}

stop abusing its dominant position. ${ }^{20}$ Valio increased its wholesale prices by 30 percent, which, according to the FCA, was more than necessary to stop the predatory pricing (Yle 1/2013). The consumer price increased in Jyväskylä by 19 percent. ${ }^{21}$

\section{The Judgment of the Finnish Market Court}

The FMC imposed a 70 million Euro penalty to Valio on June 26, 2014, which was the equal to the amount of proposed fine by the FCA to the FMC (Finnish Market Court, 2014, para. 1340). It amounts to the biggest penalty imposed in Finland to one single undertaking. However, the amount of the penalty can be changed by the FSAC. The FMC found that Valio had been in a dominant position on the Finnish basic milk market over the period of 1.3.2010 to 20.12.2012 and had abused the market by pricing its basic milks below AVC from 1.3.2010 to 31.8.2012.

Furthermore, the FMC found that the purpose of Valio's conduct had been illegal foreclosure of the market and that Valio's volume discounts to S-Group had stressed this. Valio was also ordered to pay the legal costs of Arla Finland as well as default interest amounting to 100000 Euro, which was a reasonable sum according to the FMC (Finnish Market Court, 2014, para. 13141347).

\section{Relevant Market and Dominant Position}

Valio claimed that in accordance with the previous case law, the relevant product market

20 Finnish Competition Authority, 2012, para. 13

21 Keskisuomalainen 2013, Consumer price increased by 19 per cent in Jyväskylä. Available online at: <http:// www.ksml.fi/uutiset/kotimaa/taman-verran-maitomaksaa-jyvaskylassa/1295357>. [13 January 2016] 
is liquid milk products. Which would also include fermented milks and creams. The FMC ruled, in terms of the intended purpose, basic milks were not wholly interchangeable with other liquid milk products, and so they form their own markets (Finnish Market Court, 2014, para. 200-231). In terms of relevant geographical market, the FMC considered that Finland stands out as a separate area and the market cannot be considered to be wider than this. Valio tried to argue that the market has trans-national characteristics due to the popularity of the Swedish milk in Southern Finland. The FMC rejected the argument since Arla Finland and Valio sell basic milk under the same conditions and prices to their customers throughout Finland.

The FMC found that Valio's market share on the basic milk market was over 50 per cent during the years 2008-2012 and so it was in a dominant position on the relevant market, even if its market share had fallen during same period. The FMC pointed out, inter alia, to competitor ${ }^{22}$ and customer dependence on Valio, due to its significantly broader product range and production capacity, which is only further emphasize on Valio's market power (Finnish Market Court, 2014, para. 271-356).

\section{Abuse of Dominant Position}

The competitive situation on the basic milk market had tightened since 2009 , bringing a fall in price levels. Arla's aim was to achieve a 30 per cent market share. It managed, however, to capture the position of the main

22 Since Valio is receiving almost 85 per cent of all the milk that is produced in Finland, it must have sold at least 150 million liters of milk annually to other undertakings in the dairy market. supplier to three of S-Groups' regional cooperatives at the beginning of the year 2010. The head of Valio found this as a threat and decided to drop the basic milk prices to a level no longer covering the variable costs of the manufacture. According to the FCA, Valio's prices were below AVC during the period from 1.3.2010 to 31.8.2012, which was confirmed by the FMC. Due to Valio's significant price reductions Arla's customers indicated that Arla should also reduce prices in order to continue to sell the same amount of milk as which it was selling before (Finnish Market Court, 2014, para. 336-1010).

According to the FCA's calculations, the price of raw milk is a variable cost both to Valio and its (hypothetical) competitors whose cost structures are as efficient as Valio's. The argument provided by Valio was that due to its cooperative nature, it has an obligation to receive all the raw milk that its producers produce, and so the raw milk is a fixed cost. However, the FMC stated that Valio, as a limited company, did not have a legal obligation to receive all milk produced.

According to the FMC, the colourful emails of Valio's management showed that they followed the purpose of excluding Arla Finland from the market, either in whole or in part. Valio's emails do not per se indicate that the undertaking's intention was to make a loss with its new pricing policy, but rather make a drastic price reduction, which sought to destabilize Arla Finland. However, as shown in this article, it is not necessary to provide evidence of intention to exclude a competitor in a case where pricing is below AVC. ${ }^{23}$

23 See; Chapter I. 
Objective Justifications and Responding to the Competition

Valio tried to argue that its purpose was to avoid greater losses, not to sacrifice profits, and the chosen conduct was in real terms the most profitable way of operating from the available options. According to Valio, it joined a price competition started by Arla Finland in order to avoid the losses that would be incurred by lower sales volumes. However, the FMC found that Valio did not provide sufficient evidence that the pricing below AVC was the most profitable option for it in terms of business. The FMC, moreover, announced Valio as starter of the price competition, not Arla Finland. Therefore, Valio did not have any objective reasons to defend her own conduct (Finnish Market Court, 2014, para. 232-270).

\section{The Penalty}

According to the FMC the key issue in determining the penalty was the fact that the abuse lasted for almost three years and covered all of Finland. The FMC, moreover, held that pricing below AVC is by itself an extreme restriction of competition. It was, however, Valio's volume discounts to the S-Group that increased the blameworthiness, since the S-Group had transmitted its purchase to Arla Finland.

Other increasing factors were, inter alia, Valio's huge revenue and the fact that a penalty for abuse of a dominant position had previously been imposed on Valio during 1998 (Finnish Supreme Administrative Court, 1998). Hence, Valio was convicted with penalty of 70 million Euros (Finnish Market Court, 2014, para. 1263-1290).

\section{Legal Analysis of the Judgment}

Disagreements arose, as many in the media as in the case itself, regarding Valio's form of ownership. Valio is a limited company, but, it believes in operating as a cooperative and should be treated as such. The FMC pointed out that the chosen principle of operation is a voluntary decision (Finnish Market Court, 2014, para. 412). The question is, however, whether Valio's de facto or de jure action has a more important role. If the argument that the test should be how an undertaking operates de facto is accepted, it could leave loopholes for undertakings to rely on how they supposedly operate and vice versa.

\section{Predatory Pricing Against Undertakings} Larger Than Oneself

An undertaking in global scale that is significantly larger than a dominant player on the national market is always able to return to that national market due to its larger resources, even if the national operator succeeds to drive off competition in the market. Antti Aine confirms this and points out at the threat of new entrants to the market as well. An undertaking must always consider the risk of the operation. The undertaking may lose a lot of money in such actions and investments may go down the drain if the larger and financially stronger competitor strikes again, or new competitors are able to enter the market.

The ultimate aim of predatory pricing is to achieve a larger market share at the expense of other undertakings, then raising prices to cover losses resulted from predation. The ECJ stated in the AKZO case that: 
"[Prices below average variable costs] can drive from the market undertakings which are perhaps as efficient as the dominant undertaking but which, because of their smaller financial resources, are incapable of withstanding the competition waged against them." (AKZO (1991), para. 72).

The Valio case is in this aspect particularly interesting because, in principle, the predator is a significantly larger undertaking due to the required economic power. The starting points are, therefore, quite different from United Brands and AKZO, the world's leading and largest undertakings. If this case encourages other major international undertakings to enter the Finnish market and challenge the biggest Finnish undertakings, this judgement might make the Finnish companies cautious to respond to potential price competition in fear of penalty.

In one hand, one has to keep in mind the perishable nature of milk; it is a challenge to import it to Finland and thus, in other markets it is more likely that the competition already exists. On the other hand, the competition today is increasingly getting more fierce, especially during recession, which is why undertakings are forced to find new markets. It is of course also possible that technology, including in relation to milk products, will develop in the future and open up import opportunities for different products from even further distances.

However, as an objective justification, an undertaking may have the right to a counter-attack to protect its own commercial interests. The counter-attack may be accepted if it is proportionate to the threat taking into account the undertakings confronting each other. ${ }^{24}$ Arla Foods is a significantly bigger undertaking than Valio, Europe-wide or worldwide. Can Valio's actions be considered unreasonable, even though Valio is the dominant player in Finland? The Commission has stated in its Discussion paper as: if the undertaking's internal documents show that it's conduct aims at excluding competitors from the market, the procedure is not objectively justified (DG Competition 2005, para. 131). The question is not, however, about whether it would have been possible for Valio to exclude Arla from the market or not. The Court of First Instance held, at the very least, in the France Télécom case an undertaking smaller than the plaintiff was convicted of predatory pricing. ${ }^{25}$

It must be taken into account that, even though Arla Foods is a significantly larger undertaking than Valio, due to its different global operations, it cannot be expected to decide for making losses year after year exclusively in Finland, long enough for Valio to change its pricing policy or leave the market. It is natural that the group may temporarily assist its subsidiaries, but in principle, when the group make investments and expands their operations to other countries, subsidiaries are expected to be self-reliant; to first produce back the invested money and then generate profit for the parent company. If the group finds that the investment is not profitable within a reasonable term, exit from the market is a realistic option. ${ }^{26}$

\footnotetext{
24 United Brands Company and United Brands Continentaal BV v Commission of the European Communities (1978) C-27/76, para. 189-190.

25 France Télécom v Commission of the European Communities (2007) T-340/03, para. 96-98

26 Finnish Market Court, 2014, para. 1187
} 


\section{The Valio Case After the FMC}

Valio appealed further to the FSAC, who gave an interim decision prohibiting the enforcement of the penalty until Valio's appeal in the FSAC has been resolved or is otherwise ordered (Finnish Supreme Administrative Court, 2014). According to the FSCA's own statistics the appeal process usually takes 11 months, but economic issues are reasons behind prolonging exception (Finnish Administrative Supreme Court 12/2014).

Due to the complex nature of the case, it may take up to 2-3 years to obtain the final judgment from the FSAC. The FSAC found that the FCA gave too little information on the activities of competitors to Valio during the process. The FCA was ordered to pay Valio's cost, which was a sum of 10,000 Euro in the FSAC and 5,000 Euro in the Administrative Court, plus default interest (Finnish Supreme Administrative Court, 2015).

According to Valio's Communication Director, Pia Kontunen, the final judgment in the main case will be given during the year of 2016. ${ }^{27}$ Arla Finland claimed 58 million Euro in damages from Valio. The sum will increase after interest rates to a little more than 60 million Euro. ${ }^{28}$ Valio is also likely to receive further claims of damages from the smaller actors.

27 Savon Sanomat 2015, The FCA gave too little information on the activities of competitors to Valio. Available from: < http://www.savonsanomat.fi/uutiset/ kotimaa/kho-valion-70-miljoonan-euron-sakko-jaavoimaan/2175691>. [13 January 2016].

28 Taloussanomat 2014, Arla claims 58 million euros damages. Available from: <http://www.taloussanomat. fi/paivittaistavarat/2014/11/06/arla-vaatii-valioltajattikorvauksia/201415468/12>. [13 January 2016].

\section{Valio's Product Trickery}

According to Kulutusmaidon valvontaohje $1 / 2004,{ }^{29}$ a milk product from which protein or lactose has been removed may not be called milk. Such products from which protein or lactose has been removed shall be called milk drinks (maitojuoma). It is, however, allowed to increase the amount of milk protein without need to change its name. ${ }^{30}$ Hereby they constitute, from the legal point of view, two different product markets, basic milks (perusmaidot) and special milks (erikoismaidot).

Taking advantage of the option referred above, Valio introduced a special milk called Arkimaitojuoma ${ }^{31}$ to the market in the beginning of the year 2014 ${ }^{32}$ Valio's Profit Unit Director, Tuomas Salusjärvi, commented their new products as follows: ${ }^{33}$

"There is no difference in usability. We are only able to offer it at a lower price. From the consumer's point of view, it is the low price/high-quality option for those who want to buy the cheapest milk. Of course, it also competes with basic milks as well as any other drinks that people use as a food drink. But this is not basic milk. We have the basic milk market and the special milk market, which are in a way two different things. "34

29 Free translation to English: Milk Regulation.

30 Evira. (2004). Finnish Milk Regulation. Available from: <http://www.evira.fi/attachments/elintarvikkeet/ valvonta_ja_yrittajat/kulutusmaitoasetuksen_ohjeet. pdf $>$. [13 January 2016].

31 Free translation to English: Casual milk drink.

32 Ilta-Sanomat 2014, Does Valio's new milk drink break the law? Available from: < http://www.iltasanomat.fi/ kotimaa/art-1288641066765.html>. [13 January 2016].

33 Free translation.

34 Ilta-Sanomat 2014, Does Valio's new milk drink break the law? Available from: < http://www.iltasanomat.fi/ kotimaa/art-1288641066765.html>. [13 January 2016]. 
A milk drink is, in the authorities' language: ${ }^{35}$ "a liquid milk product, which production has other processing than the fat standardization, lactose hydrolysis or the enrichment of protein, certain minerals or vitamins." The consumer considers the product tastes like milk and has the same operating characteristics as milk. ${ }^{36}$

Again one has to understand that the consumer price is not directly proportional to the wholesaler price, but the difference between consumer price of basic milk and Arkimaitojuoma was $€ 0.31$ in Jyväskylä when Valio brought the new product to the market. ${ }^{37}$ For a product that otherwise costs a little more than one euro per litre, the difference is quite large, taking into account the previously mentioned fact of Finns' milk consumption. A consumer does not see any differences between these products. Due to the penalty of 70 million Euro, it can be assumed that Valio calculated its prices quite accurately. On the special milk market with very different milks, it might be difficult to calculate and prove how much a product costs as products differ.

Antti Aine assesses that even if a product was the same, the market may differ. He gives the example of car tires, in which the product itself is the same, regardless of whether it is sold to consumers or manufacturers. However, the number of automobile factories is limited, but the

\footnotetext{
35 Free translation.

36 Makuja 2014, Milk vs. milk drinks. Available from: $<$ http://www.makuja.fi/artikkelit/1852965/ajankohtaista/maitojuomat-vastaan-tavalliset-maidot-mitka-ovattodelliset-erot/>. [13 January 2016].

37 Talouselämä 2014, Milk drink can cause problems to Valio. Available from: $<\mathrm{http}$ ://www.talouselama.fi/uutiset/halpismaitojuoma-voi-ajaa-valion-uusiin-ongelmiin-3450240>. [13 January 2016].
}

orders are typically large and, accordingly, the number of consumers is unlimited and they usually buy four tires. Furthermore, Aine stresses that it is not impossible that an undertaking can be found guilty of predatory pricing if the it opens up a new product market. This is due to the product's introduction; pricing below the marginal costs occurs in order to gain consumers.

Nonetheless, milk product trickery can still cause harm to Valio since the FCA will carry out its control measures ex-post. The FCA's Research Director, Sanna Syrjälä, states that if Valio's Arkimaitojuoma is a substitute product for basic milks, it is bound by the same obligations with regard to the basic milks. ${ }^{38}$ On the other hand, the FMC ruled that from the perspective of their intended use, basic milks are not wholly interchangeable with other dairy liquid products (Finnish Market Court, 2014, para. 244). The ECJ ruled in the United Brands case that bananas create their own market, since other fruits were not so soft and easy to eat for children, sick and elderly (United Brands (1978), para 31). That judgment has been widely criticized in legal literature, earning the name 'banana fallacy'. ${ }^{39}$

The FMC's judgment in the Valio case is similar to that extent to the judgment of the United Brands case. It remains to be seen whether FMC's reasoning will be remembered as the 'milk fallacy' and whether it is possible to take advantage of this loophole on other markets where the products are classified legally. However, it is

\footnotetext{
38 Ilta-Sanomat, 2014.

39 Leivo, K, Leivo T, Huimala, H \& Huimala, M. (2012). EU:n ja Suomen Kilpailuoikeus, $2^{\text {nd }}$ edn, Helsinki: Talentum, p. 68
} 
at least theoretically possible that the FSAC will change that part of FMC's judgment, even though the judgment otherwise would remain the same.

\section{CONCLUSION}

One problem with current EU Competition law might be that consumer welfare is valued above the welfare of producers, although this is not spelled out clearly. ${ }^{40}$ Especially in the recent recession, those undertakings who achieved their dominant positions before the recession have a significant advantage over smaller ones and companies with fewer assets, as dominant players can withstand more losses. Achieving the dominant position by itself has helped them significantly and given them the opportunity to increase their market shares without abuse, because competition rules are focused on protecting the consumer, not the position of competitors. On the other hand, the rules of the jungle apply in EU Competition law - the purpose of EU Competition law is to protect efficient competition, not ineffective competitors. ${ }^{41}$

Antti Aine, however, points out that a crisis situation may provide a foundation for new undertakings, since larger undertakings cannot necessarily afford to act on the same basis for long, although they usually survive the recession. The current EU competition law policy has received criticism to the effect that it actually leads to inefficiency and prevents the achievement of the aim of market integration. ${ }^{42}$ One alternative

\footnotetext{
40 Bishop, S \& Walker, M. (2010). The Economics of EC Competition Law: Concepts, Application and Measurement, $3^{\text {rd }}$ edn, London: Sweet \& Maxwell, p. 32

41 Leivo et al. 2012, Op.Cit. p. 770

42 Van den Bergh, R \& Camesasca, P. (2001). European
}

solution for this conflicting situation could be to aspire to the model closer to that of the United States, where the recoupment of losses needs to be proved. It would therefore be possible to ascertain that the conduct indeed has harmed the competition. ${ }^{43}$

The judgment in the Valio case could, in contrast, result in an opposite outcome if it was taking place in the United States. Recoupment of losses by increasing the price would have been much more difficult and slower than the usual means. Now, Valio was able to raise the price substantially in a single price increase, justifying it by the order of the FCA. The current trend in EU competition law may be the complete reverse of that of the United States. For example, after reading the Intel case one might get the impression that operating below variable costs would be prohibited entirely, regardless of the effects (Intel Corp. v European Commission (2014) T-286/09).

The current EU competition policy may result in multi-national undertakings overthrowing national players in the market or taking over a significant share of the current market shares. It is likely, however, that the national players will remain, at least as small players on the market. A monopoly or a significant dominance is less harmful when it is only nation-wide rather than when it is world-wide. It may not be wrong to say that the Valio case has changed the Finnish dairy market permanently. The most significant changes are the emergence of a new market for milk drinks and the increased

Competition Law and Economics - A Comparative Perspective, Oxford: Intersentia, p. 305

43 Gal, M. (2007). "Below-Cost Price Alignment: Meeting or Beating Competition?", New York University Law and Economics Working Papers, Paper 95. 
market share of private label products. ${ }^{44}$ The question about the classification of products remains unanswered. It will be interesting to see if the judgment in the Valio case will be remembered as the 'milk fallacy', if the FSAC will change the judgment of the FMC and if the FCA will start a new investigation.

To conclude, it is likely that the FSAC will not entirely change the judgment of the FMC. Actually, the only possibility for a turn in the case, to Valio's advantage, would be a radical change in the calculation method, having the prices used by Valio exceeding the ATC.

\section{BIBLIOGRAPHY}

Alkio, M \& Wik, C. (2009). Kilpailuoikeus. Helsinki: Talentum.

Arla. (2014). Arla in Finland. Available online at: $<$ http://www.arla.fi/tietoameista/arla-suomessa/>. [13 January 2016].

Bishop, S \& Walker, M. (2010). The Economics of EC Competition Law: Concepts, Application and Measurement, $3^{\text {rd }}$ edn, London: Sweet \& Maxwell.

Case C-202/07 P France Télécom SA v Commission of the European Communities [2009] ECLI:EU:C:2009:214.

Case C-27/76 United Brands Company and United Brands Continentaal BV $v$ Commission of the European Communities [1978] ECLI:EU:C:1978:22.

$44 \quad$ Private label products, grocery stores' own brands, already reached 50 per cent market share, whereas the drop of the market share of Valio's basic milk continued to as low as 22 per cent (Keskisuomalainen 2015). However, Valio's product trickery had yielded results and its Arkimaitojuoma had received a good reception from customers (Turun Sanomat 2014).
Case C-62/86 AKZO Chemie BV v Commission of the European Communities [3/7/1991] ECLI:EU:C:1991:286.

Case T-286/09 Intel Corp. v European Commission [2014]ECLI:EU:T:2014:547.

Case T-340/03 France Télécom v Commission of the European Communities [2007] ECLI:EU:T:2007:22.

Dabbah, M. (2010). International and Comparative Competition Law. New York: Cambridge University Press.

Dairy Foods (2013). Arla Food's revenue in 2012. Available from: <http://goo.gl/ PzS9NV> [13 January 2016].

Dhall, V. (2008). Competition Law Today: Concepts, Issues, and the Law in Practice. Oxford: Oxford University Press.

European Commission (2009), Communication from the Commission - Guidance on the Commission's enforcement priorities in applying Article 82 of the EC Treaty to abusive exclusionary conduct by dominant undertakings OJ C 45, p. 7-20 (24 February 2009).

European Union. (2008), Consolidated Version of the Treaty on the Functioning of the European Union, 2008 O.J. C $115 / 47$.

European Union. (2010), Consolidated Version of the Treaty on European Union, 2010 O.J. C 83/01.

Evira. (2004). Finnish Milk Regulation. Available from: <http://www.evira. fi/attachments/elintarvikkeet/valvonta_ja_yrittajat/kulutusmaitoasetuksen_ohjeet.pdf $>$. [13 January 2016]. 
Finnish Administrative Supreme Court 12/2014, Appeal statistics. Available from: <http://www.kho.fi/material/ attachments/kho/aineistoa/tilastoja/ d1DGRBo1H/KHO.fi.pdf>. [13 January 2016].

Finnish Competition Authority. (2012), Kilpailuviraston määräys lopettaa kilpailurajoitus ja esitys markkinaoikeudelle seuraamusmaksun määräämiseksi, 20.12.2012.

Finnish Market Court 6/2013, The FMC rejected Valio's application to prohibit provisionally the implementation of the FCA's decision. Available from: $<$ http://goo.gl/7KGqPV>. [13 January 2016].

Gal, M. (2007). 'Below-Cost Price Alignment: Meeting or Beating Competition?', New York University Law and Economics Working Papers, Paper 95.

Ilta-Sanomat. (2014), Does Valio's new milk drink break the law? Available from: $<$ http://www.iltasanomat.fi/kotimaa/ art-1288641066765.html>. [13 January 2016].

Jones, A \& Sufrin, B. (2012). EU Competition Law: Text, Cases, and Materials, $4^{\text {th }}$ edn, Oxford: Oxford University Press.

Keskisuomalainen. (2013). Consumer price increased by 19 per cent in Jyväskylä. Available from: <http://goo.gl/ kSdTFz>. [13 January 2016]

Keskisuomalainen. (2015). Changes in the Finnish Milk Market. Available from: $<$ http://goo.gl/7rCGPZ>. [16 January 2016].
Leivo, K, Leivo T, Huimala, H \& Huimala, M. (2012). EU:n ja Suomen Kilpailuoikeus, $2^{\text {nd }}$ edn, Helsinki: Talentum.

Makuja. (2014). Milk vs. milk drinks. Available from: <http://www.makuja.fi/ artikkelit/1852965/ajankohtaista/ maitojuomat-vastaan-tavalliset-maidot-mitka-ovat-todelliset-erot/>. [13 January 2016].

Market Court of Finland (2013), Kilpailu- ja kuluttajaviraston päätöksen täytäntöönpanon väliaikaisesta kieltämisestä, 458/12/KR ja 36/13/KR, 28.6.2013.

Market Court of Finland (2014), MAO:467 \& 468/14 Kilpailuvirasto v. Valio Oy, 458/12/KR \& 36/13/KR, 26.06.2014. Moisejevas, R, Novosad, A \& Bite, V. (2012). "Costs Benchmarks as Criterion for Evaluation of Predatory Pricing", Jurisprudence, 19(2): 585-603.

Parliament of Finland (2011), Kilpailulaki, 12 August 2011.

Rosenblatt, H, Armengod, H \& Scordamaglia-Tousis, A. (2013). "Predatory Pricing in the European Union”, European Antitrust Review, pp. 2125.

Savon Sanomat. (2015). The FCA gave too little information on the activities of competitors to Valio. Available from: $<$ http://goo.gl/GIkROA>. [13 January 2016].

Sullivan, LA. (1977). Handbook of the Law of Antitrust. Berkley: West Publishing Co.

Supreme Administrative Court of Finland (1998) KHO:1998:65 Kilpailuneu- 
vosto v. Valio Oy, 3482/1/97, 11.11.1998.

Supreme Administrative Court of Finland (2014) KHO Muu päätös 2442/2014, 19.8.2014.

Supreme Administrative Court of Finland (2015) KHO Muu päätös 3348/2015, 18.11.2015.

Supreme Court of the United States (1911), Standard Oil Co. of New Jersey v. United States, 221 U.S. 1, 15.04.1911.

Supreme Court of the United States (1993), Brooke Group Ltd. v. Brown \& Williamson Tobacco Corp., 509 U.S. 209, 21.06.1993.

Talouselämä. (2014). Milk drink can cause problems to Valio. Available from: $<$ http://www.talouselama.fi/uutiset/ halpismaitojuoma-voi-ajaa-valionuusiin-ongelmiin-3450240>. January 2016].

Taloussanomat. (2014). Arla claims 58 million euros damages. Available from: $<$ http://goo.gl/1PMrk3>. [13 January 2016].

Turun Sanomat. (2014). Private label products take over market shares. Avail- able from: $<$ http://goo.gl/ChLPZj $>$. [13 January 2016].

United States Congress. (1890). Sherman Antitrust Act, 2 July 1890.

Valio. (2013). Valio's result in the year 2012. Available from: $<$ http://www. valio.fi/yritys/valion-tulos-vuonna2012-kaikilla-mittareilla-hyva/>. [16 January 2016].

Van den Bergh, R \& Camesasca, P. (2001). European Competition Law and Economics - A Comparative Perspective, Intersentia, Oxford.

Wish, R \& Bailey, D. (2012). Competition Law, $7^{\text {th }}$ edn, Oxford: Oxford University Press.

Yle 1/2013, The FCA denies it has demanded Valio to raise the price of milk. Available from: <http://goo.gl/Oj2DbQ>. [13 January 2016].

Yle 8/2013, Finns as milk consumers. Available from: <http://goo.gl/GKIgEU>. [13 January 2016].

Yle 2014, Valio gives rough statements against and with the FCA. Available from: <http://goo.gl/GR04KR>. [13 January 2016]. 